\title{
A NEW DETERMINATION METHOD OF VERY LOW FE CONTAMINATION BY UFS*
}

Dian-Tong Lu, Zheng Qingcheng", Ian V. Mitchel1"*, P. L. F. Hemment ${ }^{* * *}$, H. Ryssel ${ }^{* * * *}$ Institute of Low Energy Nuclear Physics, Beijing Normal University, Beijing 100875

China

"Physics Department, Jiangxi University, Nanchang 330047, Jiangxi, China

"Physics Department, University of Western Ontario,London, Ontario, Canada N6A 3K7

***Department of Electronic and Electrical Engineering, University of Surrey, Guildford, Surrey GU2 5XH, UK.

****Fraunhofer-Arbeitsgruppe, fur Integrierte Schaltungen, Bauelementetechnologie, Artilleriestrasse 12, D-8520 Erlangen, Germany.

\section{ABSTRACT}

We have produced very low Fe-dose $\left(10^{8}-10^{9} \mathrm{Fe} / \mathrm{cm}^{2}\right)$ implanted Si samples. A new method of Ultraviolet Fluorescence Spectra (UFS) measurements has been used to determine the contents of $\mathrm{Fe}$ on the surfaces of Fe-samples. We find that the Fe-impurities have their own ultraviolet fluorescent peak wavelength at room temperature and their characteristic spectral peak intensities are proportional to the $\mathrm{Fe}$-doses (Fe-concentrations) in $\mathrm{Fe}$ implanted $\mathrm{Si}$ samples. This method is very sensitive, efficient and nondestructive for testing the $\mathrm{Fe}$ contamination on silicon. Some SOI (Silicon on Insulator) wafers and VLSI chips were evaluated with the UFS method. The results indicate that the UFS method is able to measure the very low Fe-contamination. The limit is below $\left(10^{8}-10^{9}\right) \mathrm{Fe} / \mathrm{cm}^{2}$ or $\left(10^{13}-10^{14}\right) \mathrm{Fe} / \mathrm{cm}^{3}$ in Si samples.

* This work was supported by the National Natural Science Foundation of China.

\section{INTRODUCTION}

The fabrication of today's most advanced integrated circuits is required to avoid some metal contamination. With shrinking device dimensions and thickness of insulating lavers down to $100 \AA$, the high content of metal impurities $\mathrm{Fe}$, Ni etc. causes more failure and less reliability of semiconductor devices. The most traditional surface sensitive techniques, like Auger electron spectroscopy or X-ray photoelectron spectroscopy, are hampered by too high detection limit of about $10^{13}$ atom/ $/ \mathrm{cm}^{2}$ [1] [2]. With the total $\mathrm{x}$-ray fluorescence (TXRF) method, absolute detection limits for transition metals are in the picogram range, corresponding to about $10^{11}$ atom $/ \mathrm{cm}^{2}$. It is difficult to determine the limit of $10^{10} \mathrm{Fe} / \mathrm{cm}^{2}$ using the above analysis.

In this contribution, we report a new technique: Ultraviolet Fluorescence Spectra (UFS). We have found the impurities of $\mathrm{Fe}$ and Ni have their own ultraviolet fluorescent peak wavelength at room temperature. When the excitement ultravioles wavelength $\lambda_{\mathrm{ex}}=350--360$ $\mathrm{nm}$, there is an iron characteristic peak at the wavelength of $\lambda_{\mathrm{em}}=371,383$ and $399 \mathrm{~nm}$; when $\lambda_{\mathrm{ex}}=330--350 \mathrm{~nm}$, there is a nickel peak at $\lambda_{\mathrm{em}}=367 \mathrm{~nm}$.

The characteristic spectral peak intensities $I_{\mathrm{f}}$ are proportional to the content of the metal impurities C. They obey Stokes Law:

In our case $\mathrm{KLC} \ll 1$

$$
\mathrm{I}_{\mathrm{f}}=A \eta \mathrm{I}_{0}\left(1-\mathrm{e}^{-\mathrm{KLC}}\right)
$$

$$
\mathrm{I}_{\mathrm{f}}=\mathrm{AI}_{0} \eta \mathrm{KLC}=\mathrm{AI}_{0} \mathrm{~K}^{*} \mathrm{C}
$$

where $\eta$ is the ultraviolet fluorescent efficiency of the metal; $A$ is the illumination area on the

$(0-7803-3062-5)$ 
sample; $\mathrm{I}_{0}$ is the excitement ultraviolet intensity; $\mathrm{K}$ and $\mathrm{L}$ are absorption coefficient and wavelength respectively. In this work, we measure the $A\left(2.5 \mathrm{~mm}^{2}\right), \mathrm{L}(297 \mathrm{~nm}), \mathrm{I}_{0}$, and $\mathrm{K}^{*}$ using the UFS data from the standard wafers. Then we determine the $\mathrm{Fe}$ and $\mathrm{Ni}$ contents of SOI wafers by formula (1). We can obtain very high sensitivity up to $\left(10^{13}-10^{14}\right)$ atom $/ \mathrm{cm}^{3}$ (about $10^{8}-10^{9}$ atom $/ \mathrm{cm}^{2}$ ).

\section{EXPERIMENTAL RESULTS}

\subsection{Standard Fe-implanted wafers and UFS data}

In order to get the Fe-standard sample, we use very careful cleaned wafers n-Si(100) $6-8 \Omega-\mathrm{cm}, \mathrm{Fe}$ implanted at $50 \mathrm{Kev}$ with doses: $1.0 \times 10^{9}, 1.0 \times 10^{10}, 1.0 \times 10^{11}, 1.0 \times 10^{12}$ and $1.0 \times 10^{13} \mathrm{Fe} / \mathrm{cm}^{2}$ respectively, then annealed at $140{ }^{\circ} \mathrm{C}$ for 30 minutes. The corresponding concentration of Fe near the surface $\left(R p=446 \mathrm{~A}^{\circ}\right)$ is $1.1 \times 10^{14}, 1.1 \times 10^{15}, 1.1 \times 10^{16}, 1.1 \times 10^{17}$ and $1.1 \times 10^{18} \mathrm{Fe} / \mathrm{cm}^{3}$, respectively.

Fig. 1 shows the Fe-LFS results, the intensity $I_{f}$ as the function of wavelength $\lambda(\mathrm{nm})$, from the Fe-standard wafers by the ultraviolet fluorometer F-3010. It is clear that the intensity of the Fe-UFS peaks increases with the Fe content which obey the Stokes formula (1). We can obtain the ultraviolet fluorescent efficiency $\eta$ and absorbtion coefficient $\mathrm{K}$ at three $\mathrm{Fe}$ UFS peak wavelengths from Fig. 1 and formula (1).

Fig. 2 is the Fe-UFS intensity $I_{\mathrm{f}}$ at wavelength 371,383 and $399 \mathrm{~nm}$ as function of the Fe-dose in the Fe standard samples.
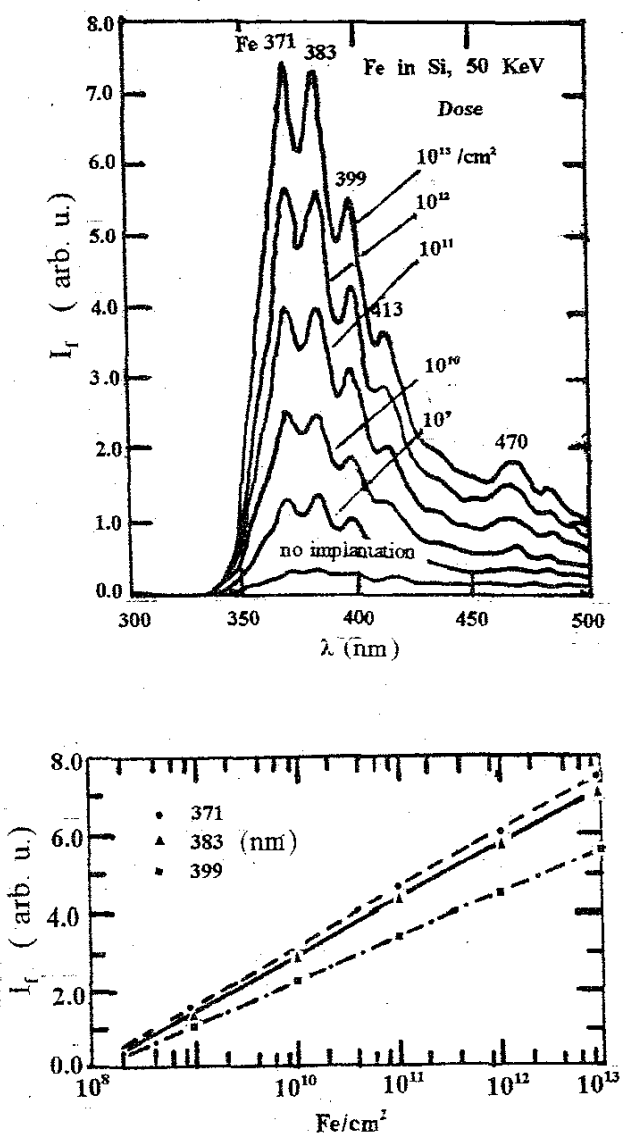

Fig. $1 \mathrm{Fe}$-UFS peak intensity $\mathrm{I}_{\mathrm{f}}$ as function of wavelength $(\lambda=371,383,399 \mathrm{~nm})$ and $\mathrm{Fe}$-dose $\left(10^{9}, 10^{10}, 10^{11}, 10^{12}, 10^{13} \mathrm{Fe} / \mathrm{cm}^{2}\right.$ and noimplantation) wafers from the Fe-standard wafer.
Fig. $2 \mathrm{Fe}$-UFS peak intensity $I_{\mathrm{f}}$ at $\lambda=371,383$, $399 \mathrm{~nm}$ as function of $\mathrm{Fe}$-standard dose $\left(10^{\circ}\right.$, $10^{10}, 10^{11}, 10^{12}$ and $10^{13} \mathrm{Fe} / \mathrm{cm}^{2}$ ) 


\subsection{UFS data from SIMNI and SIMOX films}

Four SOI-SIMNI (Separation by Implantation of Nitrogen) and eleven SOI-SIMOX (Separation by Implantation of Oxygen) wafers with deferent condition were made in Erlangen, Surrey and Beijing Normal University. The UFS data were measured by the ultraviolet fluorometer F-3010 and RF-540 made in Japan. Using the data from Fig.1 and 2, we obtained the Fe contents on SIMNI and SIMOX films. Table 1 is Fe-UFS data and Fe contents from Germany SOI-SIMNI. The peak intensity at $\lambda=383 \mathrm{~nm}$ from the surface of the sample is very low; the concentration of $\mathrm{Fe}$ is about $(2-3) \times 10^{14} \mathrm{Fe} / \mathrm{cm}^{3}$. The peak intensity at $\lambda=399 \mathrm{~nm}$ from the backside of the samples is strong; the content of $\mathrm{Fe}$ is $(1-2) \times 10^{16} \mathrm{Fe} / \mathrm{cm}^{3}$. Table 2 is Fe-UFS data and contents from Germany SIMOX films and comparative wafer Japan $\mathrm{n}-\mathrm{Si}(100)$. The concentration of $\mathrm{Fe}$ is $(2-4) \times 10^{14} \mathrm{Fe} / \mathrm{cm}^{3}$ (except SK20T) on the surface of the samples and $(1-3) \times 10^{16} \mathrm{Fe} / \mathrm{cm}^{3}$ on the backside surface. Table 3 is Fe-UFS data and contents from UK-SIMOX wafers and the comparative samples: US-Si, Japan Si. The Fe concentration near the surface is $(1.5-3.3) \times 10^{14} \mathrm{Fe} / \mathrm{cm}^{3}$; near the backside surface is (7.2$8.3) \times 10^{16} \mathrm{Fe} / \mathrm{cm}^{3}$. Table 4 is Fe-UFS data and contents from BNU-SIMOX. The concentration of $\mathrm{Fe}$ is $(2.5-4) \times 10^{14} \mathrm{Fe} / \mathrm{cm}^{3}$ near the surface, $(1.8-2.4) \times 10^{16} \mathrm{Fe} / \mathrm{cm}^{3}$ near the backside surfaces, and $6.5 \times 10^{14} \mathrm{Fe} / \mathrm{cm}^{3}$ near the polished-mirror-backside surface of No.3.

Table 1 Fe-UFS data from Germany SOI-SIMNI

\begin{tabular}{|c|c|c|c|c|c|c|}
\hline No. & $\begin{array}{l}\text { Surface } \\
\text { Peak } \\
\lambda(\mathrm{nm})\end{array}$ & $\begin{array}{l}\text { Surface } \\
\mathrm{I}_{\mathrm{r}} \quad 2^{\text {to }}\end{array}$ & $\begin{array}{l}\text { Surface } \\
10^{14} \\
\mathrm{Fe} / \mathrm{cm}^{3}\end{array}$ & $\begin{array}{l}\text { Back } \\
\text { Peak } \\
\lambda(\mathrm{nm})\end{array}$ & $\begin{array}{l}\text { Back } \\
\text { i. } 2^{10}\end{array}$ & $\begin{array}{l}\text { Back } \\
10^{16} \\
\mathrm{Fe} / \mathrm{cm}^{3}\end{array}$ \\
\hline$S K 2 T$ & 583 & $4.6-5$ & 2.3 & 383 & 98 & 0.4 \\
\hline SK $24 \mathrm{~T}$ & 393 & $4.6-5$ & 2.3 & 399 & 200 & 1.0 \\
\hline Sk:21T & 383 & $4.6-5$ & 2.3 & 399 & 440 & 2.2 \\
\hline $5 \mathrm{~K}, 327$ & 383 & 6.0 & 3.0 & 399 & 426 & 2.1 \\
\hline US-Si & 383 & 4.2 & 2.2 & & & \\
\hline
\end{tabular}

Table 3 Fe-UFS data from UK-SIMOX

\begin{tabular}{|c|c|c|c|c|c|c|}
\hline No. & $\begin{array}{l}\text { Suriace } \\
\text { Peak } \\
i(\mathrm{~nm}) \\
\end{array}$ & $\begin{array}{l}\text { surface } \\
4,2^{10}\end{array}$ & $\begin{array}{c}\text { Surface } \\
10^{1 / 4} \\
\mathrm{Fe}^{\prime / \mathrm{cm}^{3}} \\
\end{array}$ & $\begin{array}{l}\text { Back } \\
\text { Peak } \\
\text { L (nn) }\end{array}$ & $\begin{array}{l}\text { Basck } \\
I_{f} 2^{16}\end{array}$ & $\begin{array}{l}\text { Back } \\
10^{16} \\
\mathrm{Fe} / \mathrm{cm}^{2}\end{array}$ \\
\hline Uk: 1 & 383 & 3 & 1.5 & 399 & 1664 & 8.3 \\
\hline$U K^{\prime} \cdot A$ & 383 & 6.5 & 3.3 & 399 & 1632 & 8.2 \\
\hline UK $-B$ & $\$ 83$ & 5 & 2.5 & 399 & 1446 & 7.2 \\
\hline US-S: & 383 & 2.4 & 1.2 & & & \\
\hline $\operatorname{lnp} s$ & 183 & 7 & 3.5 & $3 \%$ & & 001 \\
\hline
\end{tabular}

Table 2 Fe-UFS data from Germany SOI-SIMOX

\begin{tabular}{|c|c|c|c|c|c|c|}
\hline No. & $\begin{array}{l}\text { Surface } \\
\text { Peak } \\
\lambda(\mathrm{nm})\end{array}$ & $\begin{array}{c}\text { Surface } \\
\mathrm{I}_{\mathrm{f}} 2^{10} \\
\end{array}$ & $\begin{array}{l}\text { Surface } \\
.10^{\prime:} \\
\mathrm{Fe} / \mathrm{cm}^{\prime}\end{array}$ & $\begin{array}{l}\text { Back } \\
\text { Peak } \\
2(\mathrm{nn})\end{array}$ & $\begin{array}{l}\text { Back } \\
1+2^{\text {re }}\end{array}$ & $\begin{array}{l}\text { Eack } \\
10^{1 t} \\
\text { Fecicr }\end{array}$ \\
\hline SKIIT & 383 & 8 & 40 & 799 & 272 & 1.4 \\
\hline SKI2T & 383 & 7 & 3.5 & 399 & 416 & 2.1 \\
\hline Sk20T & 383 & & & 399 & 392 & 3.0 \\
\hline SK16T & 383 & 4 & 20 & 599 & 448 & 2.2 \\
\hline
\end{tabular}

Table 4 Fe-UFS data from BNU-SIMOX

\begin{tabular}{|c|c|c|c|c|c|c|}
\hline No & $\begin{array}{l}\text { Surface } \\
\text { Peak } \\
\lambda \text { (nm) }\end{array}$ & $\begin{array}{l}\text { Surface } \\
l_{F} \quad 2^{16}\end{array}$ & $\begin{array}{l}\text { Surface } \\
10^{14} \\
\text { Feicm }\end{array}$ & $\begin{array}{l}\text { Back } \\
\text { Peak } \\
H_{1}(\mathrm{~nm})\end{array}$ & $\begin{array}{l}\text { Back } \\
1_{f} 2^{16}\end{array}$ & $\begin{array}{l}\text { Back } \\
10^{16} \\
\text { Fe/cm? }\end{array}$ \\
\hline $12-1$ & 383 & 7 & 3.5 & 399 & 476 & 2.4 \\
\hline $10-6 \mathrm{H}$ & 383 & 5 & 2.5 & 399 & 216 & $1.1:$ \\
\hline 11 & 383 & 6 & 3 & 399 & 368 & 1.8 \\
\hline 3 & 383 & 8 & 4 & 387 & 13 & $0.065^{*}$ \\
\hline $3-5 \mathrm{i}$ & 383 & 6 & 3 & & & \\
\hline
\end{tabular}

\section{DISCUSSION}

Concentration of Fe from the surfaces of all the SOI wafers is very low (about $10^{14}$ $\left.\mathrm{Fe} / \mathrm{cm}^{3}\right)$. This indicates that the buried insulating layers $\left(\mathrm{SiO}_{2}\right.$ or $\left.\mathrm{Si}_{3} \mathrm{~N}_{4}\right)$ have a strong function of absorption impurities $\mathrm{Fe}$. The backside surfaces of all the SOI wafers are weakly polluted. The content of $\mathrm{Fe}$ is about $10^{16}$ atom $/ \mathrm{cm}^{3}$. This means that the rough surface on backside of SOI wafers is easily polluted during the SOI performance. The polished backside surface (as a mirror surface) of the SOI wafer has very low content of $\mathrm{Fe}$ about $10^{14}-10^{15} \mathrm{Fe} / \mathrm{cm}^{3}$. The surface of VLSI chips has been examined by UFS method. The content of Fe depends of their fabrication environments. Some VLSI chips have very high contamination of Fe up to $10^{18}$ $\mathrm{Fe} / \mathrm{cm}^{3}$, which causes the failure of the devices. Ultraviolet Fluorescence Spectra (UFS) measurements is a very sensitive method of determining the contamination of Fe on the surface of semiconductor wafers, with limit down to $10^{13}-10^{14} \mathrm{Fe} / \mathrm{cm}^{3}$ (about $10^{9} \mathrm{Fe} / \mathrm{cm}^{2}$ ).

Reference

[1] V. Penka and W. Hub, Spectrochimica Acta. Vol.448, No.5, 483, 1989

[2] W. Bergholz, Silcon Clean Processing, Oxford, Sep. 1991. 